Abstracta Iranica

Revue bibliographique pour le domaine irano-aryen

Volume 32-33 | 2013

Comptes rendus des publications de 2009-2010

\title{
Yitzhak Magen. Mount Gerizim Excavations, vol. II. A Temple City
}

\section{Astrid Nunn}

\section{(2) OpenEdition}

1 Journals

Édition électronique

URL : http://journals.openedition.org/abstractairanica/40374

DOI : 10.4000/abstractairanica.40374

ISSN : 1961-960X

\section{Éditeur :}

CNRS (UMR 7528 Mondes iraniens et indiens), Éditions de l'IFRI

\section{Édition imprimée}

Date de publication : 1 décembre 2013

ISSN : 0240-8910

\section{Référence électronique}

Astrid Nunn, "Yitzhak Magen. Mount Gerizim Excavations, vol. II. A Temple City », Abstracta Iranica [En ligne], Volume 32-33 | 2013, document 99, mis en ligne le 01 juillet 2016, consulté le 03 octobre 2020. URL : http://journals.openedition.org/abstractairanica/40374; DOI : https://doi.org/10.4000/ abstractairanica.40374

Ce document a été généré automatiquement le 3 octobre 2020.

Tous droits réservés 


\title{
Yitzhak Magen. Mount Gerizim Excavations, vol. II. A Temple City
}

\author{
Astrid Nunn
}

\section{RÉFÉRENCE}

Yitzhak Magen. Mount Gerizim Excavations, vol. II. A Temple City. Jerusalem, 2008, 281 p.

Le Mont Gerizim, situé près de Nablus, est connu pour son temple samaritain, dont la date de fondation a pendant longtemps été très controversé. Contrairement à l'opinion selon laquelle la construction hellénistique était la phase principale d'édification, les fouilles de ces dernières années ont maintenant prouvé que ce temple remonte à l'époque achéménide, vers 450 av. J.-C. Le téménos de l'époque achéménide avait probablement trois portes (p. 114-118) et couvrait déjà la surface que gardera plus tard la cour du sanctuaire hellénistique (p. 98-103, plan p. 103 et 143). Aucun bâtiment qui devait s'y trouver ne subsiste, ceux de l'époque hellénistique ayant été construits attenant au téménos d'origine, qui lui fut transformé en cour. Presque tous les objets d'époque achéménide, qu'il s'agisse de céramique, des quelques fragments de vaisselle attique, des objets en métal (p. 210) ou des 72 monnaies, ont été retrouvés dans le temenos (p. 167-8). De toute évidence, ce sanctuaire était déjà important à l'époque achéménide. 


\section{AUTEURS}

\section{ASTRID NUNN}

Université de Munich 